\title{
Media dan Keberagaman: Analisis Pemberitaan Media Daring Seputar Pemilihan Kepala Daerah DKI Jakarta
}

\author{
Ahmad Junaidi \\ Fakultas Ilmu Komunikasi, Universitas Tarumanagara \\ Email: alexjunaidi@gmail.com
}

\begin{abstract}
ABSTRAK
Media massa berfungsi sebagai alat penyampai informasi, edukasi, hiburan dan mobilisasi. Media massa juga sebagai alat penyampai pesan, ide-ide dan gagasan, seperti gagasan keberagaman. Indonesia semenjak kelahirannya didasarkan atas dasar keberagaman dari banyak aspek, misalnya suku dan agama. Media massa di Indonesia mengalami pasang surut sejak jaman kemerdekaan, demokrasi orde lama, orde baru dan sekarang memasuki era orde reformasi. Kebebasan mulai dirasakan oleh media massa, ketika dimulaiinya era reformasi. Banyak media-media baru tumbuh di era reformasi, termasuk diantaranya media daring (media online). Selain jumlah media massa, era reformasi ini ditandai dengan kebebasan pers, termasuk didalamnya kebebasan mengespresikan gagasan dan mengritik tajam lawan yang menentang gagasan. Kebebasan pers yang dinikmati media sekarang ini banyak dilaporkan telah melewati batas, terutama melanggar kode etik jurnalistik.Penelitian ini adalah penelitian kualitatif dengan menggunakan analisis wacana dengan mengambil obyek berita-berita seputar pemilihan kepala daerah (Pilkada) Daerah Khusus Ibukota (DKI) Jakarta.Penelitian ini ingin melihat pelanggaran kode etik yang dilakukan media daring dalam meliput Pilkada Jakarta dikaitkan isu keberagaman, khususnya isu agama.Penulis menemukan sejumlah pelanggaran kode etik jurnalistik dalam berita-berita seputar Pilkada Jakarta, terutama terkait penggunaan isu agama.
\end{abstract}

Kata kunci: media massa, agama, pilkada, etik.

\section{PENDAHULUAN}

Hari-hari ini media massa nasional, khususnya di Jakarta, banyak diisi dengan berita-berita seputar kasus dugaan penistaan agama yang didakwakan kepada Gubernur Daerah Khusus Ibukota Jakarta Basuki Tjahaja Purnama atau yang lebih dikenal dengan panggilan Ahok.

Media massa, cetak, penyiaran, dan daring (online) memberitakan dugaan penistaan agama yang disangkakan kepada Ahok ini bahkan jauh sebelum kasus ini mulai disidangkan di Pengadilan Negeri Jakarta Utara pertengahan Desember tahun lalu.

Video pertemuan di Kepulauan Seribu itu, sebagaimana banyak video-video kegiatan gubernur, diunggah ke media sosial youtube.Video yang pada awalnya tidak menarik perhatian publik ini, menarik banyak penonton dan memancing banyak tanggapan setelah dipotong dan diunggah di media social facebook.

\section{MEDIA DAN KEBEBASAN}

Pada umumnya media massa dibagi dalam kategori-kategori terutama berdasarkan teknologi, bahan dan genre yang digunakan (McQuail, Teori Komunikasi Massa, : 26). Perkembangan kemajuan teknologi informasi memunculkan jenis-jenis media baru (new media) yang berbasis internet atau media daring (online media) dengan penggunaan komputer dan perangkat cerdas lainnya seperti telepon selular (smart phones).

Kebebasan pers mulai dirasakan sejak berdirinya republik ini sampai 1959 ketika Presiden Sukarno mengumumkan dekrit Presiden dan menyatakan kembali ke UUD 1945.Pers dikontrol sangat ketat. Beberapa media dibredel dan jurnalisnya dipenjarakan.Kontrol ketat terhadap media berlanjut meski Sukarno jatuh 1966 dan dilanjutkan Soeharto.Di era ini, media cetak kritis juga dibreidel, seperti Tempo, Editor dan Detik. 
Krisis ekonomi 1998, demonstrasi mahasiswa dan kerusuhan massa di bulan Mei membuat Soeharto memutuskan berhenti dari jabatannya sebagain Presiden selama 32 tahun. (Sumadiria, 2011:21-27). Jatuhnya rejim ini ditandai dengan dimulainya era kebebasan pers. Ratusan media cetak baru muncul dan juga beberapa stasiun televisi baru.

Era reformasi juga ditandai dengan pemberian otonomi yang lebih besar kepada daerahdaerah.Masa desentralisasi ini juga menumbuhkan semangat kedaerahan, etnis, termasuk ekspresi keagamaan di daerah-daerah.Bertambahnya jumlah media massa, juga didaerah-daerah, ini juga ditandai dengan meningkatnya ekpresi-ekpresi yang bersifat SARA (suku, agama, ras dan antar golongan), sebuah istilah di masa orde baru yang berusaha dihindiri dan ditutup-tutupi. (Usman Kansong 2017:85-95).

Terkait dengan Pilkada Jakarta dan penggunaan istilah yang bernuansa agama, penulis melakukan penelitian terhadap berita-berita yang dimuat dalam media daring (online media).Kesepuluh media ini dipilih berdasarkan peringkat yang dikeluarkan alexa.com, sebuah situs media yang umum dipakai untuk menentukan peringkat media daring dari berbagai media online. Kesepuluh media itu adalah: Tribunnews.com, Detik.com, Liputan6.com, Kompas.com, Merdeka.com, Okezone.com, Viva.co.id, Suara.com, Tempo.co, dan Sindonews.com. (http://www.alexa.com/topsites/countries/ID)

Berita-berita tersebut akan dikelompokkan dengan menurut kategori sederhana bersifat netral yakni tidak mendukung dan tidak menolak Ahok, positif, negatif dan netral dalam kaitannya dengan toleransi beragama, mendukung Ahok atau menolak Ahok.Penggolongan berita netral, positif, dan negatif ini didasarkan pada judul-judul dan paragraf pertama atau teras berita (lead) yang digunakan dalam berita tersebut. Judul dan paragraph pertama dalam sebuah berita sudah dapat dipakai untuk menggambarkan isi dan pesan berita (Rolnicki et, al, 2008: 36, Sumadiria, 2011: 121). Judul dan teras berita yang merupakan bagian penting, kalau tidak bias dikatakan yang terpenting dari sebuah teks berita.

Teks berita bukanlah sesuatu yang bebas dan netral.Pengaruh pemilik media yang dominan mempunyai peran yang besar dalam menentukan pesan dalam sebuah teks berita.Menganalisis teks berita bertujuan mengetahui akses kelompok dominan dalaam mempengaruhi realitas (Eriyanto, 2001: 47-53).Selanjutnya penulis akan menganalisis faktor-faktor apa saja yang mempengaruhi berita itu menjadi positif, negative dan netral.

Untuk membatasi waktu dan jumlahnya, berita-berita akan diambil pada masa kampanye resmi putaran pertama pilkada yakni 26 Oktober 2016 sampai dengan 11 Februari 2017. Beberapa kata-kata kunci digunakan untuk memudahkan mencari berita-berita pada mesin pencari seperti "Ahok" "pilkada", "agama", "Islam", dan "penistaan", dan lain-lain.

Berikut ini berita-berita dari kesepuluh media daring semasa kampanye Pilkada Jakarta:

Tabel 1.

\begin{tabular}{|c|c|c|c|c|}
\hline No. & Media & Tanggal & Judul dan Teras Berita & Sifat \\
\hline 1. & Tribunnews & $11 / 12 / 2016$ & $\begin{array}{l}\text { Judul: } \\
\text { Kasus Penistaan Agama Dinilai Bertujuan } \\
\text { Keluarkan Ahok Sebagai Peserta Pilkada } \\
\text { Teras Berita: } \\
\text { Kasus dugaan penistaan agama dengan } \\
\text { tersangka Basuki Tjahaja Purnama (Ahok) } \\
\text { dinilai sarat kepentingan }\end{array}$ & Positif \\
\hline
\end{tabular}




\begin{tabular}{|c|c|c|c|c|}
\hline & & $3 / 2 / 2017$ & $\begin{array}{l}\text { Judul: } \\
\text { Kiai Ma'ruf Amin Minta Seluruh Kader PBNU } \\
\text { Maafkan Ahok } \\
\text { Teras Berita: } \\
\text { Meski sudah dituding melakukan percakapan } \\
\text { melalui telepon dengan Ketua Umum Partai } \\
\text { Demokrat Susilo Bambang Yudhoyono (SBY) } \\
\text { terkait desakan fatwa penistaan agama, Ketua } \\
\text { Majelis Ulama Indonesia (MUI) KH Ma'ruf } \\
\text { Amin dengan sikap legowo memaafkan sikap } \\
\text { calon gubernur petahana Basuki Tjahaja } \\
\text { Purnama (Ahok). }\end{array}$ & Netral \\
\hline 2. & Detik.com & $5 / 11 / 2016$ & $\begin{array}{l}\text { Judul: } \\
\text { Terjerat Dugaan Penistaan Agama, Bisakah } \\
\text { Ahok Digugurkan dari Pilgub DKI? } \\
\text { Teras Berita: } \\
\text { Calon Gubernur DKI Jakarta Basuki Tjahaja } \\
\text { Purnama (Ahok) terbelit kasus hukum. Dia } \\
\text { dilaporkan ke Bareskrim Mabes Polri karena } \\
\text { diduga menistakan agama atas ucapannya } \\
\text { mengutip Al Maidah 51 saat berpidato di } \\
\text { Kepulauan Seribu bulan Maret } 2016 \text { lalu. } \\
\text { Judul: } \\
\text { Yusril: Saya Dukung Ahok Tetap Maju Pilgub } \\
\text { DKI } \\
\text { Teras Berita: } \\
\text { Basuki Tjahaja Purnama (Ahok) dan Yusril } \\
\text { Ihza Mahendra terlihat akrab saat menghadiri } \\
\text { acara Pagelaran Adat dan Seni Masyarakat } \\
\text { Bangka Belitung Tahun 2016 di Taman Mini } \\
\text { Indonesia Indah. Yusril pun tak lupa } \\
\text { mendoakan Ahok agar mendapat hidayah. }\end{array}$ & Positif \\
\hline 3. & Liputan6.com & $20 / 12 / 2016$ & $\begin{array}{l}\text { Judul: } \\
\text { Ahok: Zaman Pilkada Banyak Politikus Busuk } \\
\text { Teras Berita: } \\
\text { Calon petahana Gubernur DKI Jakarta Basuki } \\
\text { Tjahaja Purnama atau Ahok menjelaskan } \\
\text { maksudnya mengutip surat Almaidah } 51 \text { bukan } \\
\text { untuk menistakan agama apa pun. Maksud dari } \\
\text { perkataannya saat di Kepulauan Seribu itu } \\
\text { ditujukan untuk politisi yang menghalalkan } \\
\text { segala cara untuk menarik suara } \\
\text { Judul: } \\
\text { Pengacara: Ahok Butuh Suara Maju Pilkada, } \\
\text { Tak Mungkin Hina Islam } \\
\text { Teras berita: } \\
\text { Gubernur nonaktif DKI Jakarta Basuki Tjahaja } \\
\text { Purnama atau Ahok telah mengikuti sidang } \\
\text { kedua di gedung bekas Pengadilan Negeri } \\
\text { Jakarta Pusat. Ahok dimejahijaukan terkait } \\
\text { kasus dugaan penistaan agama. }\end{array}$ & Positif \\
\hline
\end{tabular}




\begin{tabular}{|c|c|c|c|c|}
\hline 4. & Kompas.com & $\begin{array}{l}3 / 11 / 2016 \\
11 / 12 / 2016\end{array}$ & $\begin{array}{l}\text { Judul: } \\
\text { Yusril Ajak Umat Islam Maafkan Ahok } \\
\text { Teras Berita: } \\
\text { Ketua Umum Partai Bulan Bintang (PBB) } \\
\text { Yusril Ihza Mahendra mengajak umat Islam } \\
\text { untuk memaafkan Gubernur petahana DKI } \\
\text { Jakarta, Basuki Tjahaja Purnama atau Ahok } \\
\text { Judul: } \\
\text { Kasus Penistaan Agama Disebut untuk } \\
\text { Menjegal Ahok dalam Pilkada DKI } \\
\text { Teras Berita: } \\
\text { Kasus dugaan penistaan agama dengan } \\
\text { tersangka Basuki Tjahaja Purnama (Ahok) } \\
\text { dinilai sarat kepentingan. }\end{array}$ & Positif \\
\hline 5. & Merdeka.com & $\begin{array}{l}6 / 11 / 2016 \\
10 / 12 / 2016\end{array}$ & $\begin{array}{l}\text { Judul: } \\
\text { Timses setuju Ahok tidak mundur dari Pilgub } \\
\text { DKI } \\
\text { Teras Berita: } \\
\text { Juru Bicara Tim Pemenangan Ahok- Djarot, } \\
\text { Bestari Barus mendukung langkah Basuki T } \\
\text { Purnama (Ahok) yang tidak mau mundur } \\
\text { sebagai calon gubernur DKI Jakarta. } \\
\text { Pernyataan ini menyusul aksi ratusan ribu } \\
\text { orang dari berbagai ormas keagamaan yang } \\
\text { mendesak Ahok segera diadili dan dijadikan } \\
\text { tersangka karena mencemarkan agama. } \\
\text { Judul: } \\
\text { Kasus penistaan agama dinilai bertujuan } \\
\text { keluarkan Ahok dari Pilkada } \\
\text { Teras Berita: } \\
\text { Pengamat Politik dari Universitas Indonesia } \\
\text { Arbi Sanit melihat kasus penistaan agama yang } \\
\text { menyeret Gubernur DKI Jakarta nonaktif } \\
\text { Basuki T Purnama ( Ahok) tak bisa lepas dari } \\
\text { nuansa politis. Menurut dia, kasus Ahok lebih } \\
\text { besar keinginan agar mantan Bupati Belitung } \\
\text { Timur itu keluar dari pencalonan ketimbang } \\
\text { proses penegakan hukumnya. }\end{array}$ & Positif \\
\hline 6. & Okezone.com & $\begin{array}{l}1 / 11 / 2016 \\
4 / 2 / 2017\end{array}$ & $\begin{array}{l}\text { Judul: } \\
\text { Yusril: Nasib Ahok Bisa seperti Arnoud van } \\
\text { Doorn dari Belanda } \\
\text { Teras Berita: } \\
\text { Gubernur DKI Jakarta Basuki Tjahaja } \\
\text { Purnama (Ahok) dinilai bisa saja seperti } \\
\text { Arnoud van Doorn, politikus Partai Kebebasan } \\
\text { di Belanda yang akhirnya masuk Islam. } \\
\text { Judul: } \\
\text { Duh... Pengacara Ahok Masih Anggap Kasus } \\
\text { Dugaan Penodaan Agama Masalah Politik } \\
\text { Tim Kuasa Hukum terdakwa kasus dugaan } \\
\text { penodaan agama Basuki Tjahaja Purnama } \\
\text { (Ahok) masih bersih kukuh menyatakan bahwa } \\
\text { kasus ini merupakan kasus yang berbalut } \\
\text { politik. }\end{array}$ & Negatif \\
\hline
\end{tabular}




\begin{tabular}{|c|c|c|c|c|}
\hline 7 & Viva.co & $11 / 2 / 2017$ & $\begin{array}{l}\text { Judul: } \\
\text { Survei: } 57 \text { Persen Responden Percaya Ahok } \\
\text { Menista Agama } \\
\text { Teras Berita: } \\
\text { Direktur Eksekutif Lembaga Survei Indikator } \\
\text { Politik Indonesia, Burhanuddin Muhtadi, } \\
\text { mengungkapkan bahwa pernyataan calon } \\
\text { Gubernur DKI Jakarta Basuki Tjahaja } \\
\text { Purnama alias Ahok soal surat Al-Maidah di } \\
\text { Kepulauan Seribu pada 27 September } 2016 \\
\text { memiliki konsekuensi elektoral yang sangat } \\
\text { negatif terhadap elektabilitas pasangan Ahok- } \\
\text { Djarot. Pernyataan itu pula yang membuat } \\
\text { Ahok kini jadi terdakwa kasus penistaan } \\
\text { agama. } \\
\text { Judul: } \\
\text { Arifin Ilham Ajak Jemaah Aksi } 112 \text { Doakan } \\
\text { Ahok Masuk Islam } \\
\text { Teras Berita: Ustaz Arifin Ilham memimpin } \\
\text { zikir dan doa bersama dalam rangkaian } \\
\text { kegiatan pada Sabtu, 11 Februari } 2017 \text { - atau } \\
\text { populer disebut jAksi 112 - di Masjid Istiqlal, } \\
\text { Jakarta. Kegiatan yang dimulai setelah salat } \\
\text { subuh berjemaah itu diikuti ribuan umat } \\
\text { Muslim. }\end{array}$ & Negatif \\
\hline 8 & Suara.com & $27 / 1 / 2017$ & $\begin{array}{l}\text { Judul: } \\
\text { Ahok: } 62 \text { Persen Orang Jakarta Percaya Saya } \\
\text { Menista Agama } \\
\text { Teras Berita: } \\
\text { Calon Gubernur Jakarta nomor urut dua } \\
\text { Basuki Tjahaja Purnama (Ahok) } \\
\text { mengungkapkan alasan kenapa elektabilitasnya } \\
\text { terus menerus merosot menjelang Pilkada } \\
\text { Jakarta 2017. Ahok menyebut } 56 \text { persen } \\
\text { penduduk Jakarta tidak memiliki smartphone } \\
\text { dan } 62 \text { persen masyarakat Jakarta percaya } \\
\text { dirinya telah melakukan penistaan agama. } \\
\text { Judul: } \\
\text { Politisi PPP Akui Ahok Banyak Berjasa Bagi } \\
\text { Umat Islam } \\
\text { Teras Berita: } \\
\text { Politisi Partai Persatuan Pembangunan(PPP), } \\
\text { Triyana Dewi Seroja menegaskan perhatian } \\
\text { Gubernur Petahana DKI Jakarta, Basuki } \\
\text { Tjahaja Purnama untuk menunjang kegiatan } \\
\text { keagamaan umat Islam di Jakarta sangat } \\
\text { besar. Selain menambah fungsi Islamic Center } \\
\text { di Jakarta Utara menjadi Pusat Perpustakaan } \\
\text { Sejarah Islam Indonesia, pasangan Nomor } \\
\text { Urut } 2 \text { ini juga akan membangun masjid di } \\
\text { setiap wilayah DKI Jakarta. }\end{array}$ & Positif \\
\hline
\end{tabular}




\begin{tabular}{|c|c|c|c|c|}
\hline 9 & Tempo.co & $1 / 12 / 2016$ & $\begin{array}{l}\text { Judul: } \\
\text { Baru, Pengakuan Ahok Soal Penistaan Al- } \\
\text { Maidah } \\
\text { Lead: } \\
\text { Calon Gubernur DKI Jakarta inkumben, } \\
\text { Basuki Tjahaja Purnama alias Ahok, tak bisa } \\
\text { menutupi kekecewaan atas elektabilitasnya } \\
\text { yang terus merosot menjelang pemilihan } \\
\text { kepala daerah pada Februari 2017. Dari hasil } \\
\text { survei Poltracking Indonesia terbaru, dia } \\
\text { menempati posisi kedua dengan 22 persen, di } \\
\text { bawah survei-survei sebelumnya yang } \\
\text { menempatkan dia pada posisi pertama. } \\
\text { Judul: } \\
\text { Jika Ahok Ditahan Kejaksaan, KPU: Tetap } \\
\text { Bisa Ikut Pilkada } \\
\text { Teras Berita: } \\
\text { Ketua Komisi Pemilihan Umum (KPU) DKI } \\
\text { Jakarta Sumarno tak mempermasalahkan jika } \\
\text { Kejaksaan Agung menahan Calon Gubernur } \\
\text { DKI Jakarta inkumben, Basuki Tjahaja } \\
\text { Purnama, yang telah menjadi tersangka kasus } \\
\text { dugaan penistaan agama. "Enggak apa-apa. } \\
\text { Kalau ditahan berstatus terdakwa, itu tidak } \\
\text { mempengaruhi pencalonannya," ucap Sumarno } \\
\text { kepada Tempo, Kamis, } 1 \text { Desember 2016. }\end{array}$ & Negatif \\
\hline 10. & Sindonews.com & $\begin{array}{l}10 / 11 / 2016 \\
3 / 2 / 2017\end{array}$ & $\begin{array}{l}\text { Judul: } \\
\text { Survei LSI, Kasus Penistaan Agama Bikin } \\
\text { Pemilih Ahok 'Lari' } \\
\text { Teras Berita: } \\
\text { Lingkaran Survei Indonesia (LSI) } \\
\text { menyampaikan jumlah pemilih yang belum } \\
\text { menentukan pilihan (swing voters) untuk } \\
\text { Pilkada DKI } 2017 \text { mendatang terus meningkat. } \\
\text { Sebagian besar swing voters ini adalah pemilih } \\
\text { Ahok yang terpengaruh dengan kasus } \\
\text { penistaan agama. } \\
\text { Judul: } \\
\text { Hardik Ulama NU, Peluang Ahok di Pilgub } \\
\text { DKI Semakin Tipis } \\
\text { Teras Berita: } \\
\text { Hardikan terdakwa kasus penistaan agama } \\
\text { Basuki T Purnama (Ahok) terhadap Ketua } \\
\text { MUI KH Ma'ruf Amin membuatnya terus } \\
\text { dikecam karena dianggap melecehkan ulama } \\
\text { yang sangat dihormati warga NU itu. }\end{array}$ & Negatif \\
\hline
\end{tabular}

Sebagian besar berita-berita yang dikumpulkan dalam penelitian sederhana ini menunjukkan berita-berita positif dalam pengertian mendukung Gubernur Basuki Tjahaja Purnama lebih banyak dibandingkan dengan berita-berita yang menentang Ahok terkait dalam pemberitaan kasus dugaan penistaan agama yang diturunkan oleh media-media daring. 


\section{Media dan Pengaruh Pemilik}

Media massa sekarang ini telah memasuki era industri yang ditandai dengan masuknya pengusaha-pengusaha yang selam ini tidak berlatarbelakang jurnalistik. Di era reformasi ini, perkembangan media juga ditandai dengan konvergensi dan akuisisi media oleh kelompokkelompok besar media. Saat ini, ada sedikitnya 12 kelompok media yang menguasai semua media di Indonesia, mulai dari media cetak, radio, televisi dan media daring. Dampak dari penguasaan media massa oleh dua belas konglomerasi media in terlihat dari bias-bias pemilik dalam pemberitaan. (Nugroho: 4-6).

Terkait dengan pemberitaan seputar Pilkada Jakarta 2017, tampak bias-bias pemilik dalam berita-berita yang diturunkan media daring. Berita-berita bernada positif, netral dan negatif terhadap Calong Gubernur Basuki Tjahaja Purnama terlihat dipengaruhi pilihan politik pemilik media daring.

Berita-berita yang diturunkan Tribunnews.com, Detik.com, Kompas.com, Liputan6.com, Merdeka.com dan Suara.com cenderung netral dan sebagian positif terhadap Basuki Tjahaja Purnama.Hal ini mungkin di pengaruhi oleh pemilik media-media tersebut yang berlatar belakang jurnalis atau pengusaha dan tidak terlibat politik praktis.

Sementara itu, pandangan politik pemilik terlihat dari Okezone.com, Sindonews.com, dan Viva.co.Okezone.com dan Sindonews.com adalah anggota kelompok MNC media yang dimiliki pengusaha Harry Tanoesudibyo. Harry yang juga ketua Partai Perindo baru-baru ini secara terbuka mendukung pasangan Anies Baswedan-Sandiaga Uno, lawan Ahok dalam Pilkada Jakarta. Viva.co adalah anggota grup Viva, termasuk diantaranya TVOne dan Anteve, dimiliki keluarga Bakrie. Aburizal Bakrie, yang merupakan mantan ketua Partai Golkar diberitakan tidak setuju ketika partainya, bersama dengan partai lain mendukung Ahok.

Kasus Tempo.co, yang merupakan anggota Tempo Inti Media agak berbeda. Meski mantan pemimpin redaksi dan salah satu pendiri Majalah Tempo, Goenawan Muhamad dalam cuitancuitannya di media sosial twitter mendukung Ahok, berita-berita Tempo.co cenderung negatif terhadap Ahok. Hal ini mungkin terkait dengan perseteruan Ahok dan Tempo dalam isu-isu lain seperti kasus reklamasi dan kasus-kasus lain, seperti korupsi dan isu reklamasi Teluk Jakarta.

\section{Media, Amplifikasi dan Mobilisasi}

Fungsi media massa pada awalnya sebagai media informasi, edukasi dan hiburan. Dalam perkembangannyan media kemudian berfungsi memobilisasi massa. Media dipakai sebagai alat kampanye untuk tujuan-tujuan politik, ekonomi bahkan agama.(McQuail , 2010; 108). Media menjadi penghubung komunikan dengan massa. Media massa menjadi corong penyebar gagasan, cita-cita, keresahan dari komunikan, termasuk dari mereka yang tertindas, kelompok marjinal kepada masyarakt luas. Media massa juga menjadi penghubung dengan kelompok-kelompok yang lain dalam rangka membangun aliansi-aliansi strategis yang saling membantu. (Loisa, 2016: 39-40)

Terkait dengan kasus dugaan penistaan agama yang didakwakan terhadap Gubernur Jakarta Basuki Tjahaja Purnama terlihat bagaimana fungsi media sebagai amplifikasi pesan. Pesan atau pernyataan panjang Ahok dalam kunjungan di Kepulauan Seribu 27 September yang keesokan harinya diunggah di youtube lebih dari satu jam menit belum mendapat perhatian publik yang luas. 
Kunjungan Ahok mulai menjadi perbincangan dan menyebar (viral) di media sosial, ketika video Ahok di Youtube yang awalnya berdurasi satu jam lebih dipotong menjadi 30 detik dan diunngah di media social facebook yang daya amplifikasinya lebih besar.

Menurut survey yang dilakukan oleh Asosiasi Penyelenggara Jaringan Internet Indonesia (APJII) pada 2016, jumlah penduduk Indonesia yang sudah terhubung dengan internet mencapai 132,7 juta orang dari total 256,2 juta penduduk Indonesia. Menurut survei tersebut, Facebook berada di posisi pertama sebagai media sosial yang paling banyak menyedot pengguna internet Indonesia, dengan 71,6 juta pengguna (54 persen). Media sosial berikutnya yang paling banyak dikunjungi pengguna internet Indonesia adalah YouTube. Layanan berbagi video tersebut mengantongi 14,5 juta (11 persen).(http://tekno.liputan6.com/read/2634027/3-media-sosial-favorit-penggunainternet-indonesia).

\section{Media dan Kode Etik Jurnalistik}

Kebebasan pers dan berekspresi dan kepentingan industri dan politik pemilik media berpotensi bertabrakan dengan etika jurnalistik.Dalam kode etik jurnalistik sudah jelas disbutkan bahwa media harus bersifat idependen, tidak bergantung pada pihak manapun dan bersifat netral.Dalam pasal 1 kode etik disebutkan: Wartawan Indonesia bersikap independen, menghasilkan berita yang akurat, berimbang, dan tidak beritikad buruk. (Dewan Pers; Kode Etik Jurnalistik) Independen dalam hal ini terutama memberitakan peristiwa tanpa campur tangan dan intervensi pemilik media.

Dari berita-berita yang dikumpulkan terkait Pilkada Jakarta, sebagian berita tampak media dipengaruhi pemilik media.Okezone.com dan Sindonews.com dipengaruhi pemilik medianya yakni Hary Tanoesoedibjo yang merupakan ketua umum Partai Perindo.Begitu juga dengan Viva.co yang merupakan anggota kelompok media yang dimiliki keluarga Aburizal Bakri. Bakrie yang juga mantan ketua umum Partai Golkar yang pada masa pemilihan presiden lalu tidak mendukung presiden Jokowi, pada saat pilkada ini juga tidak mendukung Ahok dalam pilkada Jakarta berlawanan dengan Partai Golkar yang mendukung Ahok.

Selain faktor independensi, kode etik jurnalistik wartawan Indonesia juga mengatur pemberitaan yang terkait isu SARA.Pasal 8 Kode Etik Jurnalistik menyebutkan Wartawan Indonesia tidak menulis atau menyiarkan berita berdasarkan prasangka atau diskriminasi terhadap seseorang atas dasar perbedaan suku, ras, warna kulit, agama, jenis kelamin, dan bahasa serta tidak merendahkan martabat orang lemah, miskin, sakit, cacat jiwa atau cacat jasmani.

Kode etik jurnalistik yang berlaku untuk semua jenis media massa ini juga diperkuat dengan kode etik media siber (cyber media) yang membahas secara khusus dan lebih detil apa yang boleh dan tidak boleh dilakukan oleh media daring.Pedoman media siber menyebutkan media siber agar tidak memuat isi yang mengandung prasangka dan kebencian terkait dengan suku, agama, ras, dan antargolongan (SARA), serta menganjurkan tindakan kekerasan.

\section{Kesimpulan dan Saran}

Sebagian besar media daring (online media) yang termasuk dalam 10 media daring terbesar di Indonesia masih mengedepakan prinsip keberagaman, toleransi beragama dan menjunjung prinsip-prinsip kode etik jurnalistik, seperti independen dan tidak membuat berita yang diskriminatif berdasar agama khususnya terkait Pilkada Jakarta. 
Sebagian kecil media dari media-media yang diteliti masih menunjukkan penggunaan isu agama untuk 'menyerang' calon gubernur Basuki Tjahaja Purnama atau Ahok. Pemberitaan yang bernada negatif terhadap Ahok ini dipengaruhi pemilik media yang mempunyai pilihan politik yang berbeda. Hal ini berpotensi melanggar kode etik jurnalistik terkait idependensi dan etika untuk tidak mendiskriminasi berdasarkan agama.

Kebebasan pers yang diperjuangan berbagai kalangan sebaiknya tetap dijaga dengan tetap mengedepankan etika jurnalistik. Pengelola media, juga pemilik, perlu diingatkan terus menerus perlunya menjunjung tinggi kode etik jurnalistik agar karya-karya jurnalistiknya tidak merugikan orang atau kelompok lain. Dengan komitmen menjujung tinggi kode etik jurnalistik, media diharapkan dapat bersama-sama menghindari konflik dan menjaga keberagaman Indonesia.

\section{REFERENSI}

Eriyanto. 2001. Analisis Wacana Pengantar Analisis Teks Media. LKIS. Yogyakarta.

Kansong, Usman. 2017. Jurnalisme Keberagaman untuk Konsolidasi Demokrasi.

MI. Publishing. Jakarta

Loisa, Riris. 2016. Wacana Vernakuler, Transformasi Identitas dan Konstruksi

Realitas Keberagaman Melalui Medium Gerakan Sosial (Studi Kasus pada

Jemaat KGI di Taman Yasmin Bogor Periode 2014-2015). Ringkasan

Disertasi. Departemen Ilmu Komunikasi Fakultas Ilmu Sosial dan

Ilmu Politik Universitas Indonesia. Jakarta.

McQuail, Denis. 2010. Teori Komunikasi Massa McQuail. Edisi 6. Buku 1.

Penerbit Salemba Humanika. Jakarta.

Nugroho, Yanuar, Dinita Andriani Putrid an Shita Laksmi. 2012. Memetakan Lansekap Industri Media di Indonesia. CIPG. Jakarta.

Rahmawati, Evi, dkk. 2013. Jurnalisme Keberagaman: Sebuah Panduan Peliputan.

Sejuk dan Hivos. Jakarta.

Rolnicki, Tom E, C. Dow Tate dan Sherri A. Taylor. 2008. Pengantar Dasar

Jurnalisme (Scholastic Journalism). Kencana Prenada Media Group. Jakarta.

Sumadiria, AS Haris.2011. Jurnalistik Indonesia Menulis Berita dan Feature

Panduan Praktis Jurnalis Profesional. Simbiosa Rekatama Media. Bandung

Surjomihardjo, Abdurrahman. 2002. Beberapa Segi Perkembangan Sejarah Pers

di Indonesia. Penerbit Buku Kompas. Jakarta

Dewan Pers. Kode Etik Jurnalistik.

http://dewanpers.or.id/peraturan/detail/190/kode-etik-jurnalistik

diunduh 5 Maret 2017.

Dewan Pers. Pedoman Pemberitaan Media Siber http://dewanpers.or.id/pedoman/detail/167/pedoman-pemberitaan-media-siber. diunduh 5 Maret 2017 